\title{
Should helmets be mandatory for skiers and snowboarders in Ontario?
}

\author{
Janet Alsop*, Sue Burlatschenko*, Sophie Gouveia*, and Karen Gowdy* \\ *Master of Public Health Program, University of Guelph. (All authors contributed equally to the paper and are listed in alphabetical order.)
}

\begin{abstract}
Every year, approximately $15 \%$ of Canadians participate in snow sports. Among skiers and snowboarders, $9 \%-19 \%$ suffer potentially disabling injuries to the head. Case-control studies have shown that ski helmets can reduce the risk of head injury by $29 \%-60 \%$. Opponents of mandatory ski helmet use have presented a series of arguments against ski helmets. However, numerous studies have demonstrated that ski helmets improve the safety of skiers and represent a benefit. Currently, there is no ski helmet legislation in Ontario. Few jurisdictions have legislation mandating the use of ski helmets. In Canada, only Nova Scotia has legislation regarding the use of ski helmets. In Canada, there are no mandatory safety standards for the manufacturing of ski helmets despite the publication of standards by the Canadian Standards Association in 2008.
\end{abstract}

Key words: Helmets, skiing, snowboarding.

\section{Introduction}

Downhill skiing and snowboarding are popular winter sports in Ontario. With over 35 alpine ski resorts in the province, the options for partaking in these activities are numerous. In the 2008-2009 season, Ontario had approximately 3.4 million skier visits to area resorts, with approximately $15 \%$ of the Canadian population over the age of 12 participating in skiing (alpine or cross-country) or snowboarding (Laplante and Lee 2009). In 2008-2009, over 2.2 million Canadians participated in alpine skiing and another 1.5 million snowboarded (Laplante and Lee 2009). Helmet use has increased in Ontario; however, in a 2011 survey, only $60 \%-65 \%$ of $18-35$ year olds admitted to wearing a helmet (Lee 2012).

As with any sport, injuries do occur; these range from simple sprains and bruises to more serious fractures and even fatalities. One study found that participation in these two sports resulted in injuries at the rate of 1.64 skiers per 1000 visits (Canadian Ski Council 2009). Of all the ski injuries that can occur, injuries to the head represent some of the most dangerous. Head injuries may result in long-term disabilities and can cost many hundreds of thousands of dollars per year to treat. Based on estimates from numerous countries, head injuries account for $9 \%-19 \%$ of all injuries reported by ski patrols and emergency departments (Russell et al. 2010). Traumatic brain injuries were among the most common injuries in skiers and snowboarders in a study conducted in Alberta (McBeth et al. 2009).

The evidence of the protective benefits of helmets has been demonstrated in many studies. In a systematic review, helmet wear was found to reduce the risk of head injury in skiing and

Corresponding author: Janet Alsop (e-mail: jea@cogeco.ca). snowboarding, with no increase in the risk of cervical spine injuries or neck injuries (Cusimano and Kwok 2010). In a metaanalysis of 12 previous studies, skiers and snowboarders wearing a helmet were found to be significantly less likely to suffer a head injury than those not wearing a helmet (Russell et al. 2010). In a recent evidence-based review by Haider et al. (2012), 16 published studies meeting the inclusion criteria were analyzed. The authors concluded that helmets reduced the severity and incidence of head injuries, but did not increase risk-taking behaviour or neck and cervical spine injuries. They recommended helmet use by all recreational skiers and snowboarders.

\section{Methodology}

PubMed, Google Scholar, Primo, and the Proquest catalogues at the University of Guelph Library were searched, using some or all of the following keywords in various combinations: ski, snowboard, helmet, injury, prevention, traumatic brain injury, spinal cord injury, and head injury. Inclusion criteria included: papers from 2005 and later, English language papers, and applicability of the title and (or) abstract. Articles were excluded based on the following criteria: papers published earlier than 2005, papers not in the English language, and papers not deemed to be helpful in answering the research question (either due to quality or content). Eleven papers were selected for review, including two survey reports (Ruzic and Tudor 2011; Scott et al. 2007), three retrospective studies (Greve et al. 2009; McBeth et al. 2009; Rughani et al. 2011), four case-control studies (Mueller et al. 2008; Hagel et al. 2010; Hagel et al. 2005; Sulheim et al. 2006.), and two randomized controlled trials (one on reaction time to peripheral stimuli and one on attenuation to sounds) (Ruedl et al. 2011; Tudor et al. 2010). 
Articles from the popular press were searched through Google using the following words: ski, snowboard, helmet, injury, prevention, legislation. Fifteen sites were examined to obtain relevant data on skier-snowboarder demographics, agency position papers, helmet legislation, helmet standards, and injury prevention data. Appendix A presents a summary of the articles reviewed.

\section{Helmets and safety}

Numerous studies have found a reduction in head injury among helmet users compared with non-helmet users. In a case-control study comparing head- and neck-injured skiers and (or) snowboarders to non-head and non-neck injured controls at 20 Quebec resorts, helmet use reduced the risk of head injury by $29 \%$. For those cases that required ambulance transport, the risk was reduced by $56 \%$ (Hagel et al. 2005). In a case-control study conducted at eight major Norwegian alpine resorts during 2002, 3277 injured skiers and snowboarders and 2992 non-injured controls were examined. Head injuries represented $17.6 \%$ of all injuries. Helmet use accounted for a $60 \%$ reduction in the risk of head injury (Sulheim et al. 2006). A third case-control study was conducted for the years 20002005 at three ski resorts in the western United States. Helmet use in 2537 skiers or snowboarders with a head injury, 1122 with a facial injury, and 565 with a neck injury were compared with 17,674 skiers and snowboarders with injuries below the neck (controls). Adjusted odds ratios were calculated for injuries to the head, face, and neck, separately. Data showed that helmets provide some protection against head injury, especially in younger people (Mueller et al. 2008).

Helmet users were also shown to have a significantly lower incidence of loss of consciousness upon striking a fixed object than non-helmet users (Greve et al. 2009). In a retrospective review of 57 head-injured children, a significantly lower number sustained a skull fracture if wearing a helmet at the time of injury (Rughani et al. 2011).

\section{Arguments against mandatory helmet use}

Currently in Ontario, organizations such as The Canadian Ski Patrol (The Canadian Ski Patrol, n.d.) and the Ontario Snow Resorts Association (Ontario Snow Resorts Association, n.d.) recommend helmets.

The following reasons are often given for not making helmets mandatory; however, there is no evidence to support them.

\section{(i) Wearing a helmet increases the risk of neck injury}

In a Quebec-based case-control study using 10 years of ski patrol data, helmet use was not found to be associated with an increased risk of neck injuries among skiers and snowboarders (Hagel et al. 2010). In the same meta-analysis that found helmets protect against head injury, no evidence of an increased risk of neck injury was found (Russell et al. 2010). In a United States case-control study, helmets did not increase the risk of injury to the neck (Mueller et al. 2008).

\section{(ii) Wearing a helmet affects hearing}

Although there is not a lot of data available on this topic, one study found helmets could impair hearing at frequencies between 2 and $8 \mathrm{kHz}$ (Tudor et al. 2010), which represents the sound of a skier or snowboarding passing by or breaking behind. However, the frequencies of the human voice were not impaired, so warning shouts could still be heard.

\section{(iii) Wearing a helmet increases risk-taking behavior}

In a survey conducted over two ski seasons, only males under 35 years of age had helmet use as a factor influencing risktaking on the slopes, with occasional helmet use having the greatest influence (Ruzic and Tudor 2011). This data would indicate that regular helmet use may decrease risk-taking behavior versus occasional helmet use. In another study of 1779 adult skiers and snowboarders, no evidence of increased risk-taking was found among helmet wearers. In fact, helmet wearers reported travelling at slower speeds and challenging themselves less than non-helmet wearers (Scott et al. 2007).

\section{(iv) Wearing a helmet affects reaction time to peripheral stimuli}

In a randomized controlled trial, Ruedl et al. (2011) found no increase in reaction time to peripheral stimuli in helmet wearers versus ski hat wearers.

\section{(v) Additional reasons}

Other reasons for not making helmets mandatory include infringing on a person's right to choose their own risk level, and the fact that helmets will not prevent all fatalities due to alpine sports. Health protection measures have been mandated successfully in the past (e.g., seatbelts in cars, bicycle helmets) and should continue to be legislated to reduce risk as much as possible. While helmets will not prevent all fatalities, the data clearly demonstrate a significant reduction in head injury risk and severity.

\section{Helmet legislation}

There are few jurisdictions that have legislation mandating the wearing of helmets for skiing and snowboarding. Legal difficulties and problems expected with enforcement have prevented widespread adoption (Jung et al. 2011).

In Europe, several countries have legislation regarding children and adolescents:

- Italy was the first country in the world to enact a law in 2004 that requires all skiers and snowboarders under the age of 14 to wear helmets (Warr 2012).

- Since 2005, children under the age of 14 in Slovenia and Croatia must wear helmets (Jung et al. 2011; Prelević 2011).

- Austria passed a similar law for those under 16 in 2009 (Jung et al. 2011; Austrian Times 2009). 
- In Norway, legislation applies to children less than 13 years of age (Thorne 2012).

In North America, where there are even fewer examples, the responsibility for enforcement is a critical issue

- New Jersey passed a law in April 2011 applying to those under the age of 18 . The law specifically states that there is no liability to ski resort operators. The liability rests with the parents and the responsibility for enforcement lies with local law enforcement. The fine is $\$ 25$ for the first offense and $\$ 100$ for the second offence (National Ski Areas Association 2010).

- In New York State, there is currently a bill before the Senate that requires helmets for children less than 14 years of age. If the bill is passed, responsibility for enforcement will lie with local law enforcement (New York Senate 2012).

- In 2010, a bill requiring anyone under 18 to wear a helmet while skiing or snowboarding was approved by the California State Senate before reaching the state assembly for a final vote (Warr 2012). In 2010 and 2011, two successive governors vetoed the bill (First Tracks 2011).

- In Canada, Nova Scotia is the only province with a helmet law. It was passed in December 2011 and came into effect in November 2012. This is the only ski and snowboard helmet law in the world that applies to both adults and children. Parents are responsible for a child under 16. The minimum fine is $\$ 250$; ski hill owners face a fine of up to $\$ 2000$. Provincial enforcement officers will monitor ski hills (Legal Information Society of Nova Scotia 2012).

\section{Non-legislative actions}

The Vancouver Charter on Skiing Safety was introduced in 2009, prior to the Vancouver Olympics in 2010. It does not have any legal standing, but was intended to promote safe skiing and snowboarding habits, including helmet use. The Charter was endorsed by the province and the Vancouver Organizing Committee for the 2010 Olympic and Para Olympic Winter Games (Brain Injury Association of Canada 2009).

At least one insurance company (Essential Travel 2012) offers a premium discount to skiers and snowboarders who use a helmet. To be fully covered for winter sports by the company's travel insurance policy, helmet use is mandatory. Customers risk invalidating their policies if a helmet is not worn.

\section{Lack of a consistent ski helmet standard in Canada}

Ski and snowboarding helmets in Canada are not governed by mandatory Canadian safety standards. In 2008, the Canadian Standards Association (CSA) published standards for a ski and snowboard helmets that met criteria for performance requirements such as shock absorption, helmet stability, and retention strength (The Canada West Ski Areas Association, n.d.). Marking and labeling requirements were also outlined (CBC News, 21 November 2012).
This standard is currently under review by Health Canada (CBC News, 21 November 2012). However, as there is no requirement for ski helmet manufacturers to conform to these standards, there are a variety of ski helmets in the Canadian market that meet other standards such as ASTM F2040, EN 1077, or Snell RS-98 (The Canada West Ski Areas Association, n.d.). The Canada West Ski Areas Association has recommended that recognition of these three standards would be sufficient to meet Canadian standards. At this time, in the absence of standards legislation, helmet manufacturers are not interested in investing the resources required to meet the proposed CSA standards.

\section{Limitations}

There are some limitations present in this review. Three of the studies examined are retrospective studies and may contain some bias such as recall bias. The true incidence of head injuries in the data can be difficult to discern because of the use of various definitions of head injury and differences in data collection methods. In addition, the personnel making the diagnoses differ amongst the studies. Geographical variances may play a role in the demographics of skiers and snowboarders with regard to ability level and safety values. Finally, underreporting may be a factor, especially with minor head injuries where treatment was not sought.

\section{Conclusion}

Ski and snowboarding are very popular winter activities in Ontario, but they can result in serious injuries, including disabling head injuries. Ski helmets can reduce the risk of head injuries, loss of consciousness, and hospitalization. The resistance against using ski helmets because of perceived increased risk to skiers has been disproven, and mandating the use of ski helmets in Ontario would ensure that Ontarians are practicing their winter activities safely. As only $60 \%-65 \%$ of Ontarians wear ski helmets on a voluntary basis, the implementation of legislation mandating the use of ski helmets would reduce the risk of head injuries. Jurisdictions where ski helmet regulations have been implemented only require children to wear helmets; a few regulations also include adolescents. In Nova Scotia, the only Canadian province with a ski helmet law, both adults and children must use a ski helmet while skiing or snowboarding. The lack of Canadian standards should not prevent Ontario from following Nova Scotia's lead for proposing its own legislation to mandate the use of ski helmets on its ski slopes.

\section{References}

Austrian Times. 2009. NÖ ski helmet law slides into action. Available at http://austriantimes.at/news/General_News/2009-03-05/11610/ N\%D6_ski_helmet_law_slides_into_action. (Accessed 21 August 2013.)

Brain Injury Association of Canada. 2009. The Brain Injury Association of Canada endorses the Vancouver Charter on Skiing Safety. Available at http://biac-aclc.ca/2009/11/25/the-brain- 
injury-association-of-canada-endorses-the-vancouver-charter-on-skiingsafety/. (Accessed 21 August 2013.)

CBC News. 2012, November 21. Ski helmets lack mandatory Canadian safety rules. Canada. Available at http://www.cbc.ca/ news/canada/story/2012/11/21/ski-helments-canadian-safety-rules. html. (Accessed 21 August 2013.)

Canada West Ski Areas Association. n.d. Ski Helmet Standards Policy. Canada. Available at http://www.cwsaa.org/policy/ski-hel met-policies.html. (Accessed 21 August 2013.)

Canadian Ski Council. 2009. Helmets and Ski Safety Facts and Stats. Ontario, Canada. Available at http://www.skicanada.org/_assets/ files/helmet\%20information\%20Nov\%202nd\%20final.pdf. (Accessed 21 August 2013.)

The Canadian Ski Patrol. n.d. Helmet Safety. Available at http:// www.csp-pcs.com/website/home/programs/safety/helmet-safety/.

(Accessed 21 August 2013.)

Cusimano, M.D., and Kwok, J. 2010. The effectiveness of helmet wear in skiers and snowboarders: A systematic review. British Journal of Sports Medicine, 44: 781-786. DOI: 10.1136/ bjsm.2009.070573.

Essential Travel. 2012. Use Your Head and SAVE. Available at http://www.essentialtravel.co.uk/travelinsurance/use-your-head/. (Accessed 21 August 2013.)

First Tracks. 2011. California Ski Helmet Bill Dies Again at Governor's Desk. Available at http://www.firsttracksonline.com/ 2011/09/08/california-ski-helmet-bill-dies. (Accessed 21 August 2013.)

Greve, M.W., Young, D.J., Goss, A.L., and Degutis, L.C. 2009. Skiing and snowboarding head injuries in 2 areas of the United States. Wilderness and Environmental Medicine, 20: 234-238. DOI: 10.1580/08-WEME-OR-244R1.1.

Hagel, B.E., Pless, I.B., Goulet, C., Platt, R.W., and Robitaille, Y. 2005. Effectiveness of helmets in skiers and snowboarders: Case-control and case crossover study. British Medical Journal, 330: 281. DOI: 10.1136/bmj.38314.480035.7C.

Hagel, B.E., Russell, K., Goulet, C., Nettel-Aguirre, A., and Pless, I.B. 2010. Helmet use and risk of neck injury in skiers and snowboarders. American Journal of Epidemiology, 171(10): 1134-1143. DOI: 10.1093/aje/kwq039.

Haider, A.H., Saleem, T., Bilaniuk, J.W., and Barraco, R.D. 2012. An evidence-based review: Efficacy of safety helmets in the reduction of head injuries in recreational skiers and snowboarders. J Trauma Acute Care Surg, 73(5): 1340-1347. DOI: 10.1097/TA.0b01 3e318270bbca.

Jung, C.S., Zweckberger, K., Schick, U., and Unterberg, A.W. 2011. Helmet use in winter sport activities - attitude and opinion of neurosurgeons and non-traumatic-brain-injury-educated persons. Acta Neurochir, 153: 101-106. DOI: 10.1007/s00701-010-0704-8.

Laplante, N., and Lee, J. 2009. 2008-2009 Canadian Skier and Snowboarder Facts and Stats. Available at http://xcski.org/news/ 2009\%20Facts\%20and\%20Stats\%20final\%20draft.pdf. (Accessed 22 August 2013.)

Lee, J. 2012. Ski Helmet Usage in Canada. Canadian Ski Council. Available at http://www.skicanada.org/_assets/files/Ski\%20Helmet\% 20usage\%20in\%20Canada\%20final.pdf. (Accessed 21 August 2013.)

Legal Information Society of Nova Scotia. 2012. Helmet Head. Available at http://www.legalinfo.org/Legal-News/helmet-law.html. (Accessed 21 August 2013.)
McBeth, P.B., Ball, C.G., Mulloy, R.H., and Kirkpatrick, A.W. 2009. Alpine ski and snowboarding traumatic injuries: Incidence, injury patterns, and risk factors for 10 years. The American Journal of Surgery, 197: 560-564. DOI: 10.1016/j.amjsurg.2008.12.016.

Mueller, B.A., Cummings, P., Rivara, F.P., Brooks, M.A., and Terasaki, R.D. 2008. Injuries of the head, face, and neck in relation to ski helmet use. Epidemiology, 19(2): 270-276. DOI: 10.1097/EDE. 0b013e318163567c.

National Ski Areas Association. 2010. Update on State Ski and Snowboard Helmet Laws. Available at http://skypig.info/pdf/Ski/ 4.pdf. (Accessed 21 August 2013.)

New York Senate. 2012. S4356-2011: Prohibits a skier from skiing in any area unless he or she is wearing a protective helmet; applicable to skiers under fourteen years of age. Available at http://open. nysenate.gov/legislation/bill/S4356-2011. (Accessed 21 August 2013.)

Ontario Snow Resorts Association. n.d. Helmet Policy. Ontario, Canada. Available at http://www.skiontario.ca/code.php. (Accessed 21 August 2013.)

Prelević, S., and Slovenia, S.I. 2011. Slovenian slopes offer alluring white pistes. Available at http://www.slovenia.si/visit/sportsleisure/ ski-resorts/slovenian-slopes-offer-alluring-white-pistes/. (Accessed 21 August 2013.)

Ruedl, G., Herzog, S., Schopf, S., Anewanter, P., Geiger, A., Burtscher, M., et al. 2011. Do ski helmets affect reaction time to peripheral stimuli? Wilderness \& Environmental Medicine, 22(2): 148-150. DOI: $10.1016 /$ j.wem.2010.12.010.

Rughani, A., Chih-Ta, L., Ares, W.J., Cushing, D., Horgan, M.A., Tranmer, B.I., Jewell, R.P., and Florman, A.P. 2011. Helmet use and reduction in skull fractures in skiers and snowboarders admitted to the hospital. J Neurosurg Pediatr, 7: 268-271. DOI: 10.3171/2010.12.PEDS10415.

Russell, K., Christie, J., and Hagel, B.E. 2010. The effect of helmets on the risk of head and neck injuries among skiers and snowboarders: A meta-analysis. Canadian Medical Association Journal, 182(4): 333-340. DOI: 10.1503/cmaj.091080.

Ruzic, L., and Tudor, A. 2011. Risk-taking behaviour in skiing among helmet wearers and nonwearers. Wilderness \& Environmental Medicine, 22: 291-296. DOI: 10.1016/j.wem.2011.09.001.

Scott, M.D., Buller, D.B., Anderson, P.A., Walkosz, B.J., Voeks, J.H., Dignan, M.B., et al. 2007. Testing the risk compensation hypothesis for safety helmets in alpine skiing and snowboarding. Injury Prevention, 13: 173-177. DOI: 10.1136/ip.2006.014142.

Sulheim, S., Holme, I., Ekeland, A., and Bahr, R. 2006. Helmet use and risk of head injuries in alpine skiers and snowboarders. Journal of the American Medical Association, 295(8): 919-924. DOI: 10.1001/jama.295.8.919.

Thorne, P., and The Independent. 2012. Ski News. Available at http://www.independent.co.uk/travel/skiing/ski-news-8300261.html. (Accessed 21 August 2013.)

Tudor, A., Ruzic, L., Bencic, I., Sestan, B., and Bonifacic, M. 2010. Ski helmets could attenuate the sounds of danger. Clinical Journal of Sports Medicine, 20(3): 173-178. DOI: 10.1097/JSM.0b013e $3181 \mathrm{df} 1 \mathrm{eb} 2$.

Warr, C-A., and eHow. 2012. Ski Helmet Regulations. Available at http://www.ehow.com/list_7240227_ski-helmet-regulations.html. (Accessed 21 August 2013.) 
Appendix A. Summary of studies of helmet use in winter sports.

\begin{tabular}{|c|c|c|}
\hline Strategy & Intervention & Example \\
\hline $\begin{array}{l}\text { Ruzic and } \\
\text { Tudor (2011) }\end{array}$ & $\begin{array}{l}\text { Risk-taking behaviour in skiers among } \\
\text { helmet wearers and non-wearers }\end{array}$ & $\begin{array}{l}\text { - cross-sectional survey } \\
\text { - risk taking while skiing is greatest in males under } 35 \text { who } \\
\text { occasionally wear helmets }\end{array}$ \\
\hline $\begin{array}{l}\text { Scott et al. } \\
(2007)\end{array}$ & $\begin{array}{l}\text { Testing the risk compensation hypothesis for } \\
\text { safety helmets in alpine skiing and } \\
\text { snowboarding. }\end{array}$ & $\begin{array}{l}\text { - } \text { cross-sectional survey } \\
\text { - } 1,779 \text { participants surveyed at } 34 \text { ski resorts } \\
\text { - helmet wearers skied and (or) snowboarded at lower } \\
\text { speeds } \\
\text { - helmet wearers took lower risks than non-helmet wearers } \\
\text { odds ratio: } 0.67 \text { (CI: } 0.50-0.88 \text { ) }\end{array}$ \\
\hline $\begin{array}{l}\text { Greve et al. } \\
(2009)\end{array}$ & $\begin{array}{l}\text { Skiing and snowboarding injuries in two } \\
\text { areas of the United States }\end{array}$ & $\begin{array}{l}\text { - retrospective cohort study } \\
\text { - helmets were considerably protective in collisions with } \\
\text { fixed objects }\end{array}$ \\
\hline $\begin{array}{l}\text { McBeth et al. } \\
(2009)\end{array}$ & $\begin{array}{l}\text { Alpine ski and snowboarding traumatic } \\
\text { injuries:Incidence, injuries patterns and risk } \\
\text { factors for } 10 \text { years }\end{array}$ & $\begin{array}{l}\text { - retrospective study } \\
\text { - records collected from Alberta Trauma registry identified } \\
196 \text { serious trauma patients over a } 10 \text { year period } \\
\text { - safety initiatives should be adopted }\end{array}$ \\
\hline $\begin{array}{l}\text { Rughani et al } \\
\text { (2011) }\end{array}$ & $\begin{array}{l}\text { Helmet use and reduction in skull fractures } \\
\text { in skiers and snowboarders admitted to the } \\
\text { hospital }\end{array}$ & $\begin{array}{l}\text { - retrospective cohort study of } 57 \text { patients; } 33 \% \text { wearing } \\
\text { helmet at time of injury } \\
\text { - } 5.3 \% \text { of the } 57 \text { patients had skull fracture and were wearing } \\
\text { a helmet vs. } 36.8 \% \text { of skull fracture not wearing helmet } \\
\text { - OR of a skull fracture in those not wearing a helmet was } \\
10.5 \text { (CI: } 1.26-87.4 \text { ) compared with helmet users }\end{array}$ \\
\hline Mueller et al. & $\begin{array}{l}\text { Injuries of the head, face, and neck in } \\
\text { relation to ski helmet use }\end{array}$ & $\begin{array}{l}\text { - case-control study involving } 21,989 \text { skiers and } \\
\text { snowboarders } \\
\text { - helmets were protective with respect to head injury (OR: } \\
\text { 0.85; CI: 0.76-0.95) } \\
\text { - no evidence that helmet use increases neck injuries }\end{array}$ \\
\hline $\begin{array}{l}\text { Hagel et al. } \\
(2010)\end{array}$ & $\begin{array}{l}\text { Helmet use and risk of neck injury in skiers } \\
\text { and snowboarders }\end{array}$ & $\begin{array}{l}\text { - case-control study in Quebec of } 3826 \text { cases and } 97,408 \\
\text { unmatched controls } \\
\text { - helmets did not increase the risk of neck injuries in skiers } \\
\text { and snowboarders (OR: } 1.09 \text {, CI: } 0.95-1.25 \text { for neck } \\
\text { injury, OR: } 1.02 \text {, CI: } 0.791 .31 \text { for cervical spine fractures } \\
\text { or dislocations) }\end{array}$ \\
\hline $\begin{array}{l}\text { Hagel et al. } \\
(2005)\end{array}$ & $\begin{array}{l}\text { Effectiveness of helmets in skiers and } \\
\text { snowboarders: a case-control and crossover } \\
\text { study }\end{array}$ & $\begin{array}{l}\text { - case-control study in Quebec of } 1082 \text { cases and } 3295 \\
\text { controls matched to cases at each hill } \\
\text { - helmets reduced the risk of any head injury (adjusted OR: } \\
0.71, \text { CI: } 0.55-0.92 \text { ) } \\
\text { - risk reduction of } 29 \% \text { for any head injury; } 56 \% \text { reduction } \\
\text { in risk for head injury requiring evacuation by ambulance }\end{array}$ \\
\hline $\begin{array}{l}\text { Sulheim et al. } \\
\text { (2006) }\end{array}$ & $\begin{array}{l}\text { Helmet use and risk of head injuries in } \\
\text { alpine skiers and snowboarders }\end{array}$ & $\begin{array}{l}\text { - case-control study of } 3277 \text { injured skiers and } 2992 \text { non- } \\
\text { injured controls at } 8 \text { Norwegian alpine resorts } \\
\text { - helmet use reduced risk of head injury by } 60 \% \\
\text { - severe head injury risk reduced by } 57 \% \text { by wearing helmet }\end{array}$ \\
\hline $\begin{array}{l}\text { Ruedel, et al. } \\
\text { (2011) }\end{array}$ & $\begin{array}{l}\text { Do ski helmets affect reaction time to } \\
\text { peripheral stimuli? }\end{array}$ & $\begin{array}{l}\text { - randomized controlled trial measuring reaction time to } \\
\text { peripheral stimuli in skiers } \\
\text { - ski helmet use did not increase reaction time to peripheral } \\
\text { stimuli }\end{array}$ \\
\hline $\begin{array}{l}\text { Tudor et al. } \\
(2010)\end{array}$ & $\begin{array}{l}\text { Ski helmets could attenuate the sounds of } \\
\text { dangers }\end{array}$ & $\begin{array}{l}\text { - Randomized controlled trial } \\
\text { - high pressure sounds may be distorted by helmets on ski } \\
\text { slopes in range of } 2-8 \mathrm{kHz}\end{array}$ \\
\hline
\end{tabular}

